\title{
Long-term change of phytoplankton in Lake Kivu: The rise of the greens
}

\author{
Edouard Rugema $^{1}$ | François Darchambeau ${ }^{2}$ | Hugo Sarmento ${ }^{3}$ | Maya Stoyneva-Gärtner ${ }^{4}$ | \\ Maria Leitao $^{5}$ | Wim Thiery ${ }^{6}$ | Adrien Latli $^{7}$ | Jean-Pierre Descy ${ }^{2}$ (I)
}

${ }^{1}$ Symbion Power Lake Kivu Ltd, RSSB Headquarters, Kigali, Rwanda

${ }^{2}$ Unit of Chemical Oceanography, University of Liège, Liège, Belgium

${ }^{3}$ Departamento de Hidrobiologia (DHb), Universidade Federal de São Carlos, São Carlos, Brazil

${ }^{4}$ Department of Botany, Faculty of Biology, Sofia University 'St Kliment Ohridski', Sofia, Bulgaria

${ }^{5}$ Bureau d'études Bi-Eau, Angers, France

${ }^{6}$ Department of Hydrology and Hydraulic Engineering, Vrije Universiteit Brussel, Brussels, Belgium

${ }^{7}$ DEMNA, Service Public de Wallonie, Gembloux, Belgium

\section{Correspondence}

Descy Jean-Pierre, Unit of Chemical Oceanography, University of Liège, Liège, Belgium.

Email: jpdescy@gmail.com

\section{Funding information}

Conselho Nacional de Desenvolvimento Científico e Tecnológico, Grant/Award Number: 309514/2017-7; Fundação

Amazônia Paraense de Amparo à Pesquisa, Grant/Award Number: 2014/14139-3

\section{Abstract}

1. Phytoplankton time-series enable the observation of recurrent seasonal patterns on community composition, but drastic shifts in community structure are rarely observed, unless linked to anthropogenic impacts (e.g. changes in nutrient inputs). Here, we report a unique case of non-seasonal, multiannual regime shift of phytoplankton community structure in Lake Kivu, East Africa, and explore the possible causes for such changes.

2. We recorded phytoplankton biomass every 2 weeks over a period of 12 years (from 2002 to 2015). Phytoplankton community previously dominated by cyanobacteria and diatoms changed considerably from 2012, with a conspicuous rise in the biomass of green algae (from 3 to 33\% lake-wide), and a decline of cryptophytes and cyanobacteria along with an increase in total chlorophyll $a$ concentration. Concomitantly, we observed significant differences in the mixed layer depth between the two periods, resulting from changes in the thermal gradient. The euphotic zone depth was also reduced in 2012-2015, probably from the higher phytoplankton biomass. Moreover, mean particulate nitrogen and phosphorus increased as well as the particulate N:P ratio.

3. Desmids (Cosmarium laeve) now dominate the mixolimnion, probably due to atelomixis, observed in high-frequency temperature measurements. We believe that decadal or multidecadal variability of climate on the Indian Ocean may be the reason for this regime shift in thermal stratification, with a strong impact in phytoplankton community structure.

4. In conclusion, our study demonstrates that tropical lakes may be subject to nonseasonal fluctuations that generate multiannual regime shifts. These regime shifts have probably never been reported previously because of the lack of long phytoplankton time-series in low latitudes.

\section{KEYWORDS}

atelomixis, climate variability, community structure, East Africa, tropical great lake 


\section{1 | INTRODUCTION}

As phytoplankton can respond quickly to changes in temperature, light, nutrient loading, and water column physical structure, the composition of the assemblage-both taxonomical and functional-may reveal natural and man-induced changes in these factors (Reynolds, 2006). There are well-documented examples of long-term monitoring of phytoplankton in temperate lakes, particularly for assessing effects of lake acidification (Ginn, Cumming, \& Smol, 2007; Vrba et al., 2003), eutrophication or oligotrophication (e.g. Anneville, Ginot, Druart, \& Angeli, 2002; Ruggiu, Morabito, Panzani, \& Pugnetti, 1998), or global warming (e.g. Sarmento, Amado, \& Descy, 2013; Stenuite et al., 2007). The response at the level of individual cell populations can be fast (days to weeks) and reflect environmental or seasonal variations, but changes in assemblage composition resulting from a change in lake status (e.g. from a reduction of nutrient loading) occur at longer time scales (Reynolds, 1992). Therefore, years of continuous observations are necessary to tell apart changes related to significant environmental trends from stochastic or seasonal variations. Typically, decades of phytoplankton monitoring, using the same methods, are needed to assess those trends.

In tropical lakes, few studies based on phytoplankton surveys have been long enough to assess changes at a multi-annual scale. Most of the time, long-term surveys were based on measurements of chlorophyll $a$ (Chla) concentration (i.e. an estimate of phytoplankton biomass), as a proxy for pelagic primary production, and gaps are often present in time series. For instance, records of Chla in Lake Tanganyika (Bergamino et al., 2010; Horion et al., 2010) have shown variations at seasonal and inter-annual scales, related to variations of the mixed layer depending on meteorological and climatic conditions, which determine water column processes in African Great Lakes (Nicholson, 1996; O'Reilly, Alin, Plisnier, Cohen, \& McKee, 2003; Maclntyre, 2012; Tierney et al., 2010; Tierney, Smerdon, Anchukaitis, \& Seager, 2013). However, the lack of continuity in records (Plisnier, Nshombo, Mgana, \& Ntakimazi, 2018) hampers straightforward interpretation of changes involved and, too often, methodological differences between past and recent surveys further complicate data processing and interpretation. Therefore, studies on tropical lakes have mostly relied on paleolimnological approaches based on various sediment archives, such as fossil diatoms (Haberyan \& Hecky, 1987) or phytoplankton pigments (SaulnierTalbot et al., 2014), with a time resolution of decades to centuries.

In deep tropical lakes, phytoplankton composition responds primarily to the alternation of stratified conditions in the rainy season with the deep mixing that occurs in the dry season: the seasonal mixing event not only increases the supply of dissolved nutrients to the euphotic zone, but also results in a higher mixed layer ( $\mathrm{Zm})$ : euphotic layer (Zeu) depth ratio (Sarmento, Isumbisho, \& Descy, 2006). In these conditions, phytoplankton is subjected to potential light limitation, leading to diatom dominance (Reynolds, 2006). By contrast, in the shallow mixed layer of the rainy season, the lower $\mathrm{Zm}$ :Zeu ratio selects for high-light-adapted phytoplankton such as green algae and cyanobacteria. The trade-off between high light and nutrient limitation in the rainy season and low light and high nutrients during the dry season has been documented in classic studies in African lakes (e.g. Hecky \& Kling, 1987; Kilham, Kilham, \& Hecky, 1986) and is a key to understanding shifts in phytoplankton composition in these lakes. Resource ratios may also play a role in determining which species may be the most successful in given conditions of light and nutrient availability (Kilham et al., 1986).

Although it has not been used extensively so far, pigment-based analysis of phytoplankton composition may provide an adequate framework to relate community composition to environmental changes. Phytoplankton marker pigments, determined by high-performance liquid chromatography (HPLC) analysis, have been used for assessing biomass at the class level, with many applications in marine, estuarine, and freshwater environments (e.g. review in Sarmento \& Descy, 2008). Estimating algal abundance from marker pigment relies on calculations using measured pigment concentrations and ratios of those markers to Chla (e.g. with CHEMTAX, Mackey, Mackey, Higgins, \& Wright, 1996). As it is based on a fast, automatic and reliable analytical technique, the pigment approach has been largely used in oceanographic studies and monitoring programmes (Jeffrey, Mantoura, \& Bjørnland, 1997), as well as in large lake studies (Descy et al., 2005; Fietz \& Nicklisch, 2004; Fietz, Sturm, \& Nicklisch, 2005; Sarmento et al., 2006). We carried out a long-term phytoplankton monitoring of the water column of Lake Kivu using this approach.

Lake Kivu is a great and deep (maximum depth of $489 \mathrm{~m}$ ) meromictic lake of the East African Rift (Figure 1). It is located north of Lake Tanganyika, at $1463 \mathrm{~m}$ above sea level. In this lake, the mixolimnion (i.e. the mixed layer of a meromictic lake) alternates between periods of complete mixing down to maximum $65 \mathrm{~m}$ and periods of stratification, during which nutrients become depleted in the euphotic zone (Figure 2; Sarmento et al., 2006; Schmid \& Wüest, 2012; Thiery, Martynov, et al., 2014; Thiery, Stepanenko, et al., 2014). The deepening of the mixed layer occurs during the dry season (June, July, August) and is primarily driven by the substantial decrease in atmospheric relative humidity during that period, which generates evaporative-driven cooling of near-surface waters, and secondly by the reduced incoming longwave radiation reaching the lake surface owing to lower cloudiness (Thiery, Martynov, et al., 2014). The strength of the stratification during the wet season varies from year to year, with notably weak stratification periods during the 2008 and 2009 wet seasons. Overall, the recent years have been marked by a slight reduction in stratification strength (Figure 2), possibly related to the transition from a wet to a drier period.

Whereas moderate to severe P-limitation of phytoplankton prevails in Lake Kivu during most of the year (Sarmento, Darchambeau, \& Descy, 2012; Sarmento et al., 2009), N-limitation may occur in the stratified rainy season, as denitrification takes place within the oxic-anoxic transition zone (Lliros et al., 2012; Roland et al., 2018). Pelagic primary production in Lake Kivu exhibits substantial variation at the seasonal scale, but also between years (Sarmento et al., 2012), as shown by the variable height of the dry season Chla peak (Darchambeau, Sarmento, \& Descy, 2014). Phytoplankton composition also varies seasonally in a predictable way, with diatoms 


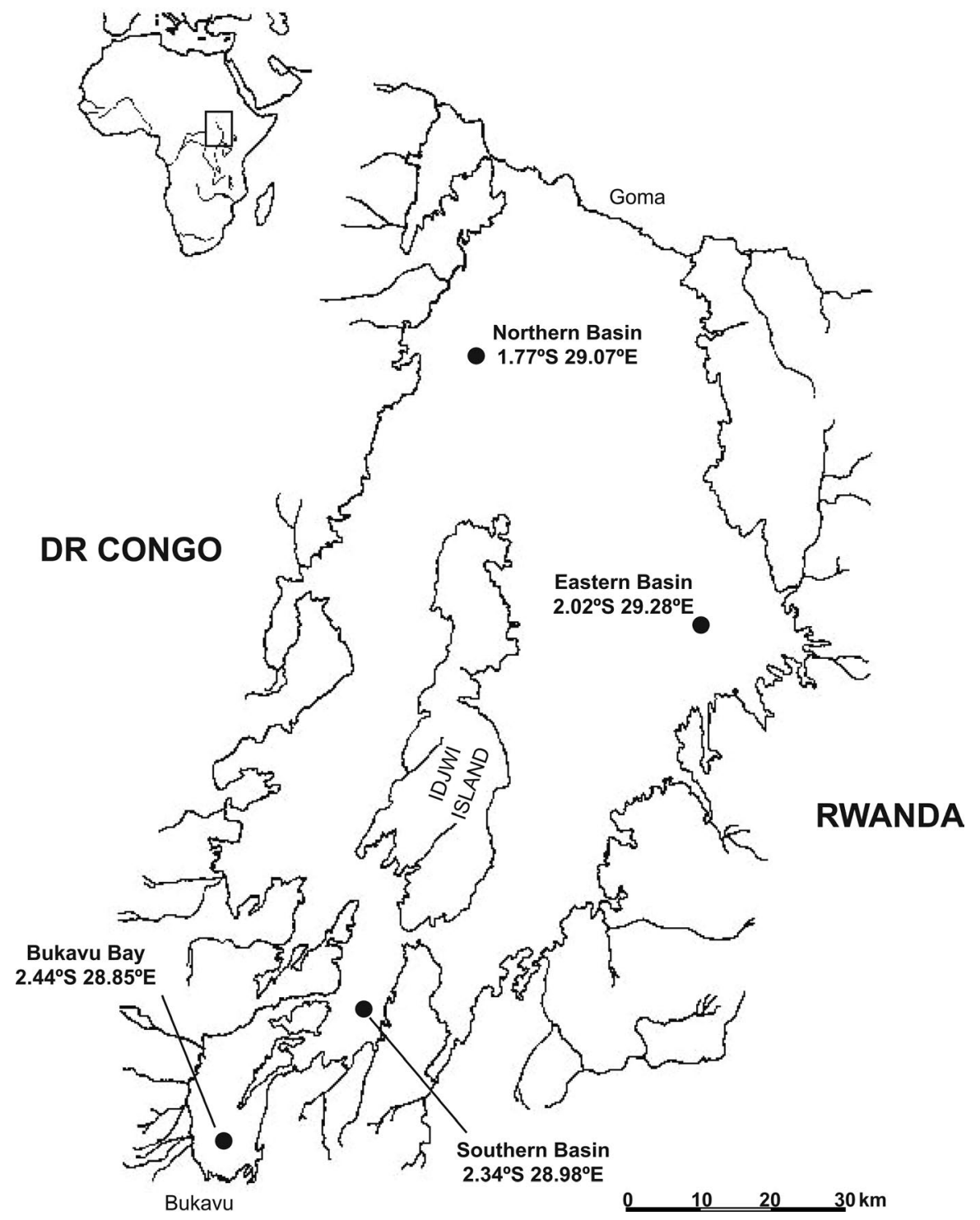

FIGURE 1 Map of Lake Kivu and location of the sampling sites. The inset shows location of Lake Kivu in the Western African Rift

being more abundant in the dry season, and cyanobacteria better developed in the rainy season (Sarmento et al., 2006, 2007). Given the remarkably low taxonomic diversity of phytoplankton in Lake Kivu, and the fact that there are few dominant species (Sarmento et al., 2007), there is a good correspondence between resolution at the class level based on marker pigments and resolution at genus/ species level, that can be obtained with microscopy. For instance, variations of diatom biomass mostly reflect variation of abundance of needle-like Nitzschia and Fragilaria, and variations of cyanobacteria type 2 biomass depends on abundance of Planktolyngbya and Raphidiopsis. Similarly, green algae are essentially composed of populations of Cosmarium laeve (Sarmento et al., 2007) and of Tetraëdron minimum (Stoyneva et al., 2012).

A phytoplankton biomass long-term monitoring (recorded over a period of 12 years, from 2002 to 2015) at the class level in Lake Kivu, allowed us to detect drastic changes in phytoplankton community structure. The main shift occurred from 2012, with a conspicuous rise in the biomass of green algae, paralleled by changes in the abundance of the other phytoplankton groups. The objective of this study is to report these changes and to examine possible explanations for them, based on the available environmental data and on the ecological strategies of the dominant taxa. Our main hypothesis was that phytoplankton responded primarily to changes in water column mixing dynamics.

\section{2 | METHODS}

The study sites were located in the northern basin (off Gisenyi $1.07^{\circ} \mathrm{S}, 29.23^{\circ} \mathrm{E}$ ) and the eastern basin (off Kibuye $2.10^{\circ} \mathrm{S}, 29.20^{\circ} \mathrm{E}$ ) of Lake Kivu, as well as in southern basin (at Ishungu) of $\left(2.34^{\circ} \mathrm{S}\right.$, $28.98^{\circ} \mathrm{E}$ ) (Figure 1). The Gisenyi and Kibuye sites are located in the deepest basin, where the exploitation of the methane present in large amounts in the deep waters has begun in the past years (for more information, see https://www.contourglobal.com/asset/ kivuwatt). Part of the data were obtained in the framework of the "Biological Baseline of Lake Kivu" (Descy \& Guillard, 2014), setup for monitoring the changes which may occur in the mixolimnion 


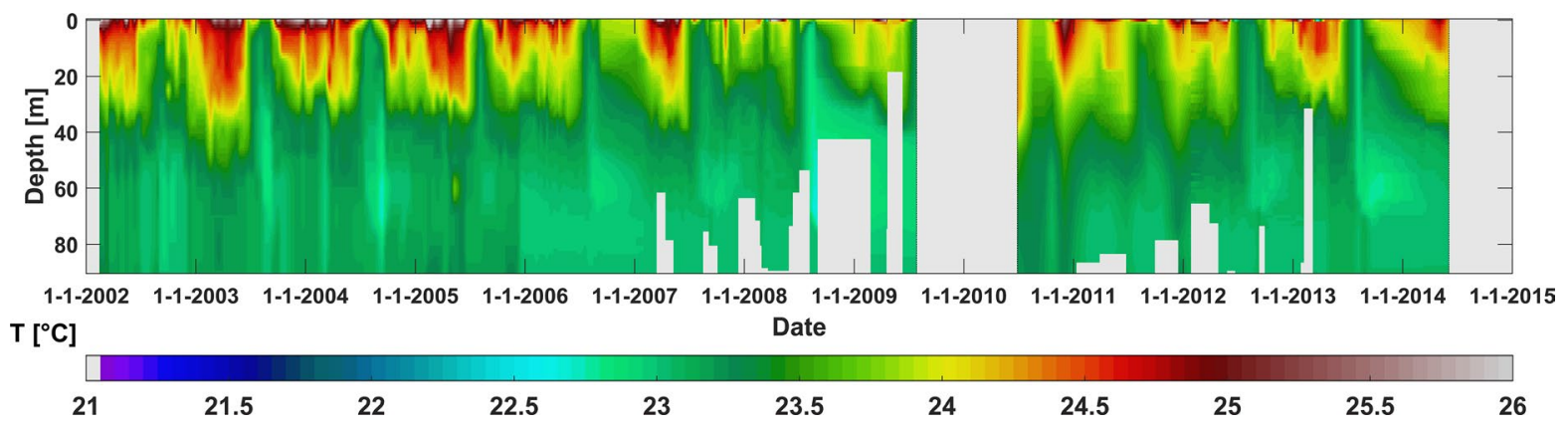

FIG URE 2 Depth-time diagram of temperature in the mixolimnion of Lake Kivu at Ishungu, southern basin, 2002-2014. White-out portions: no data [Colour figure can be viewed at wileyonlinelibrary.com]

as a result of the gas exploitation (see Wüest, Jarc, Bürgmann, Pasche, \& Schmid, 2012). In this paper, owing to the similarity of the limnological conditions, the data from Gisenyi and Kibuye sites were merged.

General physical and chemical characteristics of the lake water are described elsewhere (e.g. Borges, Abril, Delille, Descy, \& Darchambeau, 2011; Descy et al., 2012; Sarmento et al., 2006; Schmid, Halbwachs, Wehrli, \& Wüest, 2005). The lake is meromictic, with a salinity gradient located between 60 and $90 \mathrm{~m}$ depth, separating the top oxygenated layer-the mixolimnion or biozone from the deep anoxic waters extending down to $485 \mathrm{~m}$ at the deepest point. Limnological and planktological observations were made throughout the mixoliminion twice a month from March 2002 to November 2009 , and monthly afterwards. The longest time series is from the Ishungu site (2002-2015), and that from the northern-eastern basin is somewhat shorter (2005-mid 2015). Similar techniques were used throughout the study period, with use of multiparameter probes (Hydrolab DS4, Yellow Springs Instrument 6600 V2 probe and Sea \& Sun CTD M725 and 257 probes) for acquisition of vertical profiles of temperature, dissolved oxygen, $\mathrm{pH}$, and conductivity in the mixolimnion, with casts down to $70 \mathrm{~m}$ depth. There was no systematical cross-calibration, but every probe was calibrated on the day of measurement, and sometimes two probes were used. The mixed layer depth, $\mathrm{Zm}$, was determined at each occasion as the depth with the maximum downward temperature change per $\mathrm{m}$, because salinity has a marginal effect on density gradient in the top $65 \mathrm{~m}$ (Schmid \& Wüest,2012). The depth of the euphotic zone (Zeu, the depth at which light is attenuated at $1 \%$ of subsurface PAR) was estimated from the vertical attenuation coefficient measured with Li-Cor surface and submersible sensors, and from Secchi depth using conversion coefficients, determined several times during the study period from simultaneous measurements (see e.g. Darchambeau et al., 2014).

Water samples were collected using a Van Dorn or Niskin 6-L bottle, at different depths, at $5 \mathrm{~m}$ intervals in the 0-20-m layer and at $10-\mathrm{m}$ intervals in the 20-60-m layer. For each sampling depth, at least $3 \mathrm{~L}$ of water were filtered on Macherey-Nägel (Düren, Germany) GF5 filters (average retention capacity of $0.4 \mu \mathrm{m}$ ) on which pigment extraction was carried out in 90\% HPLC-grade acetone, following Sarmento et al. (2006). In addition, $2 \mathrm{~L}$ of a pooled sample of the mixed layer were filtered on a pre-combusted GF5 filter for particulate carbon $(C)$, nitrogen $(N)$, and phosphorus $(P)$ analyses. Filters were left to dry and then kept frozen until analysis. Those analyses of seston elemental composition were carried out from 2002 to 2008 using a Carlo Erba NA1500 elemental analyser for determining particulate $C$ (POC) and particulate $N$ (PON), and particulate $P(P O P)$ was measured after persulphate digestion. Molar C:N, C:P, and N:P ratios were used as indicators of phytoplankton nutrient status, as in Sarmento et al. $(2009,2012)$ and in Darchambeau et al. (2014). From 2012 to 2015, only PON and POP were measured, for the sites off Gisenyi and Kibuye, according to Valderrama (1981), so that only N:P ratios were available for comparison with the 2002-2015 period. However, a few seston analyses were performed by elemental analysis during the EAGLES project (Descy et al., 2015), allowing to obtain some C: $\mathrm{N}$ seston ratios in the lake off Gisenyi.

Phytoplankton biomass and composition were assessed throughout the study by determination of Chla and marker pigments by high-performance liquid chromatography. High-performance liquid chromatography analysis of phytoplankton extracts was carried out using the Wright et al. (1991) gradient elution method, with a Waters system comprising a photodiode array detector and a fluorescence detector. Calibration was made using commercial external standards (DHI, Denmark). For estimating phytoplankton abundance at the class level, pigment concentrations were processed with the CHEMTAX software (Mackey et al., 1996). Lake Kivu data processing followed a procedure similar to that of Descy et al. (2005), allowing estimating Chla biomass of green algae, Chrysophytes, diatoms, Cryptophytes, dinoflagellates, and cyanobacteria, taking into account variations of pigment ratios with season and depth. Phytoplankton biomass was expressed either as the mean over the whole mixolimnion $(0-60 \mathrm{~m})$, per unit volume $\left(\mathrm{mg} \mathrm{Chla} / \mathrm{m}^{3}\right)$, or as $\mathrm{mg} \mathrm{Chla} / \mathrm{m}^{2}$, by integrating the Chla measurements at the different sampled depths. Based on previous knowledge of the phytoplankton composition in Lake Kivu analysed using microscopy (Sarmento et al., 2007), the following phytoplankton groups were considered:

- Diatoms and chrysophytes, which have chlorophylls c and share fucoxanthin as main marker pigment; diatoms also have diadinoxanthin and diatoxanthin; due to analytical problems of the HPLC 
technique (i.e. the incomplete separation of myxoxanthophyll and violaxanthin or diadinoxanthin), diatoms were not confidently distinguished from chrysophytes: these two classes were regrouped and treated as diatoms + chrysophytes.

- Green algae, which have chlorophyll b, lutein, neoxanthin, zeaxanthin, and violaxanthin

- Cyanobacteria type 1 (T1), which have zeaxanthin at high concentration

- Cyanobacteria type 2 (T2), which have echinenone and often aphanizophyll and/or myxoxanthophyll in addition to zeaxanthin

- Cryptophytes, with chlorophyll c, alloxanthin, and $\alpha$-carotene

- Dinoflagellates, with chlorophyll c, peridinin, and diadinoxanthin

On some occasions, a supplementary $50-\mathrm{ml}$ sample was preserved immediately after collection with Lugol's solution and neutral formaldehyde (2-4\% final concentration) for microscopic identification of main taxa, according to Sarmento et al. (2007). In addition, a monthly survey was carried out off Kibuye from November 2012 to April 2013, with collection of 1-L samples from 3 depths $(-5,-20,-40 \mathrm{~m})$, corresponding to the layers usually observed in Lake Kivu during stratification periods. After Lugol addition, these samples were left to settle for $24 \mathrm{hr}$ and the sedimented material was resuspended in $100 \mathrm{ml}$ lake water, and preserved with formaline and further microscope examination. Microscope examination was carried out by the Bi-Eau consultancy (Angers, France), using the Utermöhl technique (AFNOR 2006) for determining phytoplankton abundance and biovolume at the best achievable identification level. To estimate the biovolumes, each taxon was assigned to a stereometrical form (Rott, 1981). For the main species, we used cylinder (with rounded or elliptical base), parallelepiped (with square or rectangular base), and revolution ellipsoid. Single measurements were done at light microscope with $\times 1,000$ magnification and using the Olympus DPSoft program. Cell surface and volume were calculated using average dimensions. The surface:volume ratio (S/V) and the greatest axial linear dimension $(\mathrm{m})$ were used for determination of primary phytoplankton life strategies (C, S, R, and transitional types - Grime $(1979,2001)$ and Reynolds (1988), summarised and completed by Olrik (1994) and Reynolds (2006).

\section{1 | Continuous measurements at high resolution (lake logger data)}

Mooring lines were installed on the two monitoring platforms located off Gisenyi: these lake loggers (Precision Measurement Engineering, USA) consisted of different sensors for continuous recording of temperature (with eight thermistors attached every $10 \mathrm{~m}$ from 0 to 70 $\mathrm{m})$. The lake loggers allowed acquisition of high temporal resolution data (every $5 \mathrm{~min}$ ) in the 2012-2014 period (Descy \& Guillard, 2014) and generated a file with raw data every $6 \mathrm{hr}$; the data were used to assess the physical status of the top $70 \mathrm{~m}$ of the water column at high temporal resolution.

\section{2 | Statistical analyses}

Using the available limnological and planktological data, we constructed a data matrix containing 426 observations gathered at the three sampling sites, by averaging all variables between 0 and $20 \mathrm{~m}$, i.e. approximately the euphotic zone. The limnological variables included in the data matrix were mixed layer depth $(\mathrm{Zm})$, maximum temperature in the mixolimnion (Max_T), minimum temperature in the mixolimnion (Min_T), average temperature in the mixolimnion (T_avg), Delta_T (Max-T - Min_T), Schmidt stability index, Secchi depth (Secchi), depth of the euphotic zone (Zeu), Zm : Zeu ratio; when available, PON, POC, C:N molar ratio, POP, C:P molar ratio, $\mathrm{N}: \mathrm{P}$ molar ratio. The planktological data were $\mathrm{Chla}$ and the biomass of main phytoplankton groups (expressed as $\mu \mathrm{g}$ Chla/L, as calculated with CHEMTAX), i.e. green algae, cryptophytes, cyanobacteria T1, cyanobacteria T2, dinoflagellates and diatoms (chrysophytes were summed up with diatoms, as the distinction of the two classes based on pigments was uncertain). We performed a one-way analysis of variance (ANOVA) to test for significant differences between two time periods (2002-2008 and 2012-2014) for the biotic variables measured. Normality of data and residuals were analysed with a Shapiro-Wilk test (Shapiro \& Wilk, 1965).

Using the R-software (R 3.5 version, Development Core Team, 2010) and the ADE4 package (Chessel, Dufour, \& Thioulouse, 2004), we carried out a factorial correspondence analysis on the phytoplankton data in order to examine changes of phytoplankton biomass and composition over the years. In addition, we determined the trends in the variation of abiotic (limnological data) and biotic parameters (planktological data) over the 2002-2014 period using generalised additive models (Fewster, Buckland, Siriwardena, Baillie, \& Wilson, 2000). Variables were standardised by site for reducing potential spatial or methodological betweensites bias and highlighting global tendencies at the scale of the whole lake. Temporal trends were modelled as a smooth nonlinear function of time. Autocorrelation error was reduced by adding a residual autocorrelation structure, optimised by minimising the Akaike information criterion over several combinations of autoregressive parameters (Zuur, leno, Walker, Saveliev, \& Smith, 2009). Finally, we carried a canonical correspondence analysis (CCA), a well-known multivariate gradient analysis with constrained ordination (Ter Braak, 1986), on the data from the deep basin, for which values of all variables were available, in order to identify the key environmental variables driving the biomass of the phytoplankton classes.

\section{3 | RESULTS}

The total phytoplankton biomass in the northern and eastern basins ranged from 10 to $224 \mathrm{mg} \mathrm{Chla} / \mathrm{m}^{2}$ with a mean of $90 \pm 38.6 \mathrm{mg}$ $\mathrm{Chla} / \mathrm{m}^{2}$ between 2005 and 2014. In the southern basin, the biomass ranged between 10 and $348.7 \mathrm{mg} \mathrm{Chla} / \mathrm{m}^{2}$ with a mean of $77.6 \pm 38.9 \mathrm{mg}$ Chla $/ \mathrm{m}^{2}$ between 2002 and 2014 . 
Two periods can be distinguished based on Chla and phytoplankton composition in the lake (Figures 3 and 4): in the 20022008 period, mean Chla concentration in the euphotic layer was $2.2 \mu \mathrm{g} / \mathrm{L}$; cyanobacteria were the dominant group of phytoplankton, with close to $50 \%$ of Chla on average, while diatoms represented $25 \%$, closely followed by cryptophytes ( $22 \%$ of Chla); green algae contributed a few percent. From 2012 to 2014, mean Chla was $2.8 \mu \mathrm{g} / \mathrm{L}$ and the composition changed markedly: diatoms and green algae increased, and cyanobacteria and cryptophytes decreased to $<20 \%$ together, on average. Similar changes were observed at Ishungu: a decrease of cyanobacteria and cryptophytes was observed, paralleled by an increase in green algae, from $2 \%$ in 2002-2008 up to 30\% of Chla in 2012-2014. Despite the large interannual variations of Chla concentration in Lake Kivu, a significant increase in Chla concentration $(p<0.001)$ was observed at all sites in the post-2012 data.

Microscopic analyses carried out on samples collected monthly off Kibuye showed that the green algae were represented mainly by the desmid Cosmarium laeve, which was the single highly dominant taxon among the green algae, followed by the coccal Tetraëdron minimum (normal and lemon-shaped; see Stoyneva et al., 2012). Figure 5 allows to compare the morphological parameters of the main phytoplankton taxa and to assess the ecological strategies. With their high $\mathrm{S} / \mathrm{V}$ and high $\mathrm{m}$ and $\mathrm{mS} / \mathrm{V}$, the diatoms (Nitzschia bacata and Fragilaria danica) and the filamentous cyanobacteria (Raphidiopsis curvispora, Planktolyngbya limnetica, and Planktolyngbya contorta), can be considered as S strategists, i.e. stress-tolerant taxa. By contrast, with their medium-sized to small cells and their lower S/V, the different forms of Cosmarium (C. laeve, small and large, and Cosmarium polygonatum) and of Tetraëdron seem to exploit a transitional S-R (see discussion) life-strategy (Figure 5, right panel).

\section{1 | Statistical analyses}

The factorial correspondence analysis showed the interannual variation of phytoplankton composition, with a temporal gradient, discriminating the years dominated by cyanobacteria T2 (20022008) from the years dominated by green algae (2013-2014), with a transition period in 2012 (Figure 6).

Modelling phytoplankton group variations using generalised additive model (Figure 7) helped to better understand the change in abundance of the main phytoplankton groups. All groups exhibited large variations over time, except for cyanobacteria T1, which remained relatively constant, and of dinoflagellates, which were barely developed most of the time. Two groups, cyanobacteria T2 and cryptophytes, showed a decrease from 2011 to 2012 onward, whereas diatoms (+chrysophytes) and particularly green algae increased in this period (Figure 7). These changes were statistically significant (Table 1).

A similar trend analysis, carried out on the available limnological data (Figure 8), showed an increase of the depth of the mixed layer from 2012, which resulted from a decrease of the thermal gradient (Delta T) within the mixolimnion. This weaker thermal gradient mainly resulted from an increase in T_min (see Figure 8 and Table 2), while T_max decreased. A slight increasing trend was observed for Chla, with a corresponding decrease of the depth of the euphotic layer.

Both PON and POP increased in Lake Kivu between the 20032008 period and the 2012-2014 period (Figure 9). Despite greater variability in 2012-2014, the differences were statistically significant. Sestonic N:P ratios were also significantly different between the two periods (Figure 9), with a higher average N:P ratio in 20122014, suggesting greater $P$ limitation, occurring essentially in the rainy season, with $N: P$ reaching 80 , exceeding the range reported by Sarmento et al. (2012). Deeper vertical mixing in the dry seasons 2013 and 2014 resulted in increased P availability, reflected in the lower N:P ratio (down to 12 , i.e. similar to Sarmento et al.'s data). A few C:N seston ratios ( $n=6)$ from 2012 to 2013 gave a mean of $10.1 \pm 1.6$, i.e. similar to that published by Sarmento et al. (2012), based on the 2002-2008 data.

The CCA performed on the data from the northern and eastern basin (Figure 10) showed that environmental variables explained

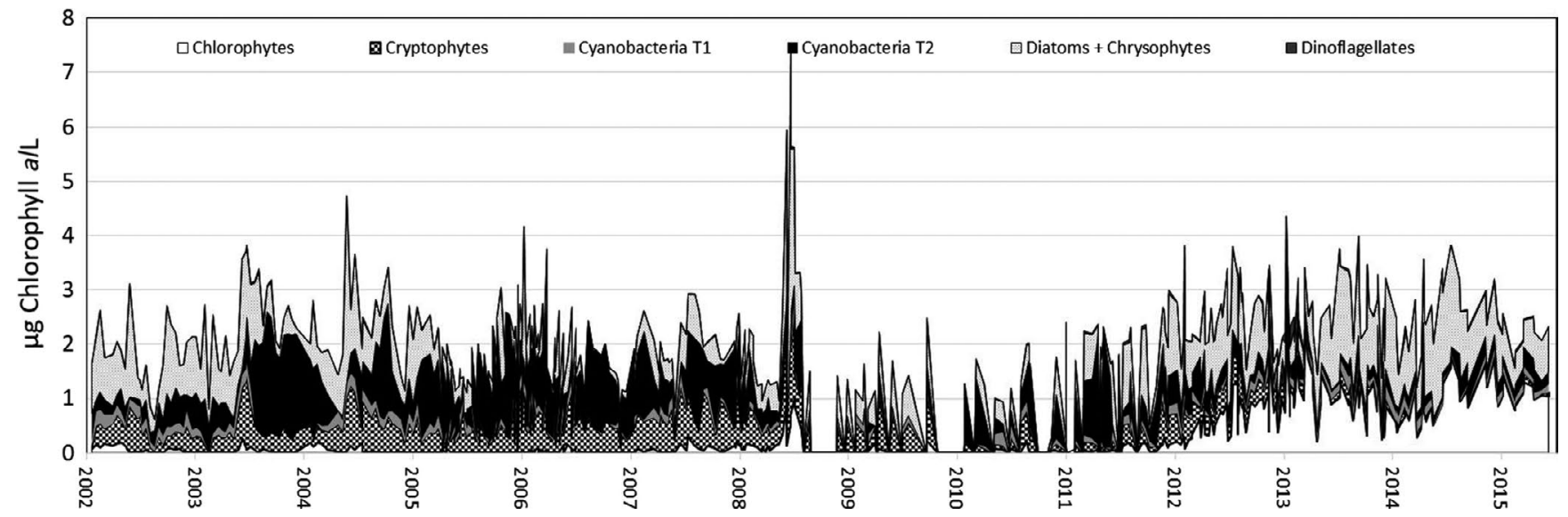

FIGURE 3 Phytoplankton biomass and composition from marker pigment analysis by high-performance liquid chromatography averaged over the upper 60-m layer in Lake Kivu 2002-2015. Fewer data were acquired between September 2008 and February 2010. To represent the longest time series, the data from the northern and the southern basin were merged 

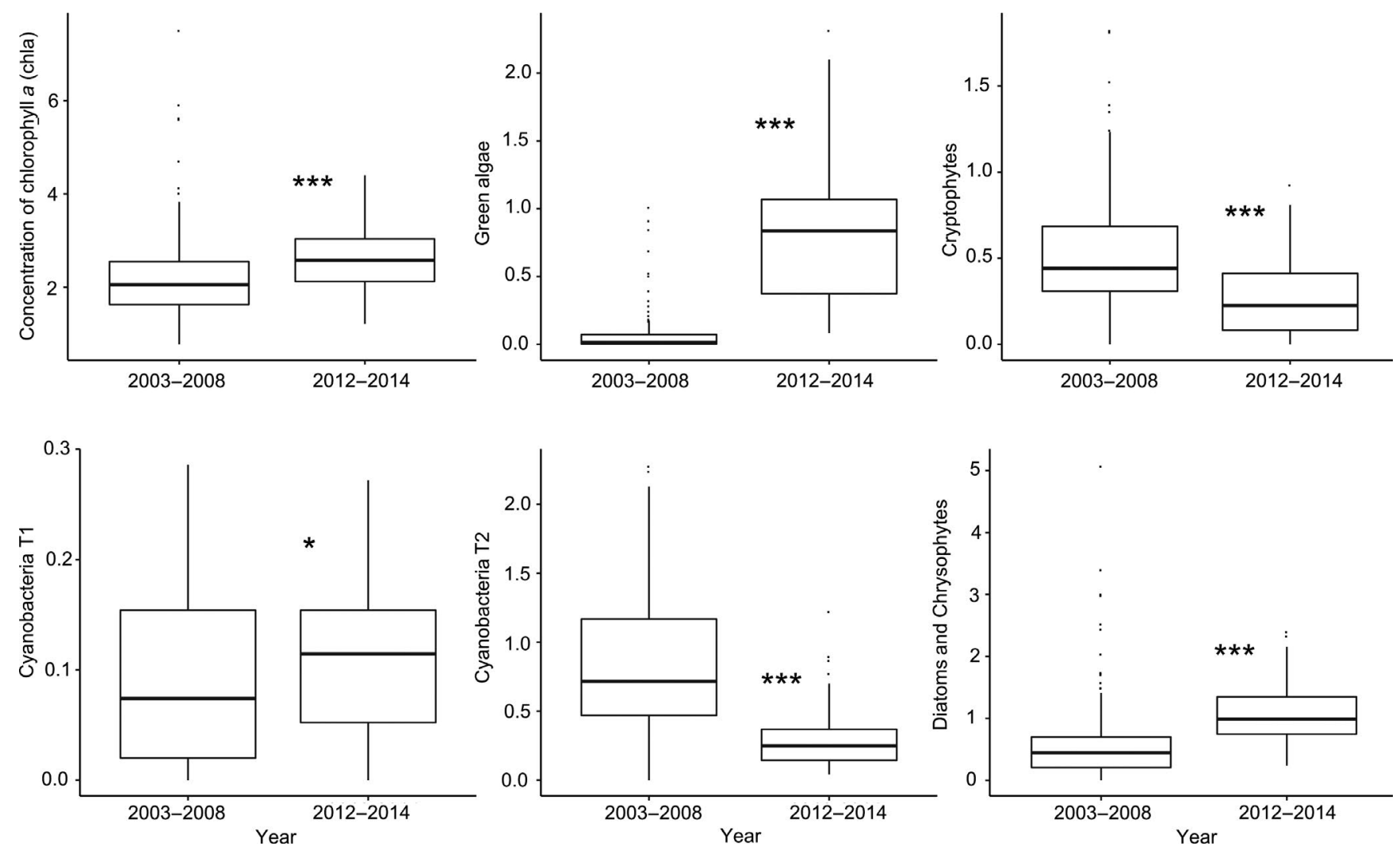

FIGURE 4 Box-plots showing the changes in chlorophyll $a$ and phytoplankton group abundance in Lake Kivu, between the periods 2002-2008 and 2012-2014. Dark lines represent the median and the middle boxes encompass 50\% of the observations from lower (25\%) to upper (75\%) quartiles. The upper and lower whiskers describe, respectively, the extreme quartiles. Outliers are displayed as black circles. Stars indicate statistical significance at $p<0.05(*), p<0.01\left({ }^{* *}\right)$, and $p<0.001\left({ }^{* * *}\right)$ tested with an ANOVA
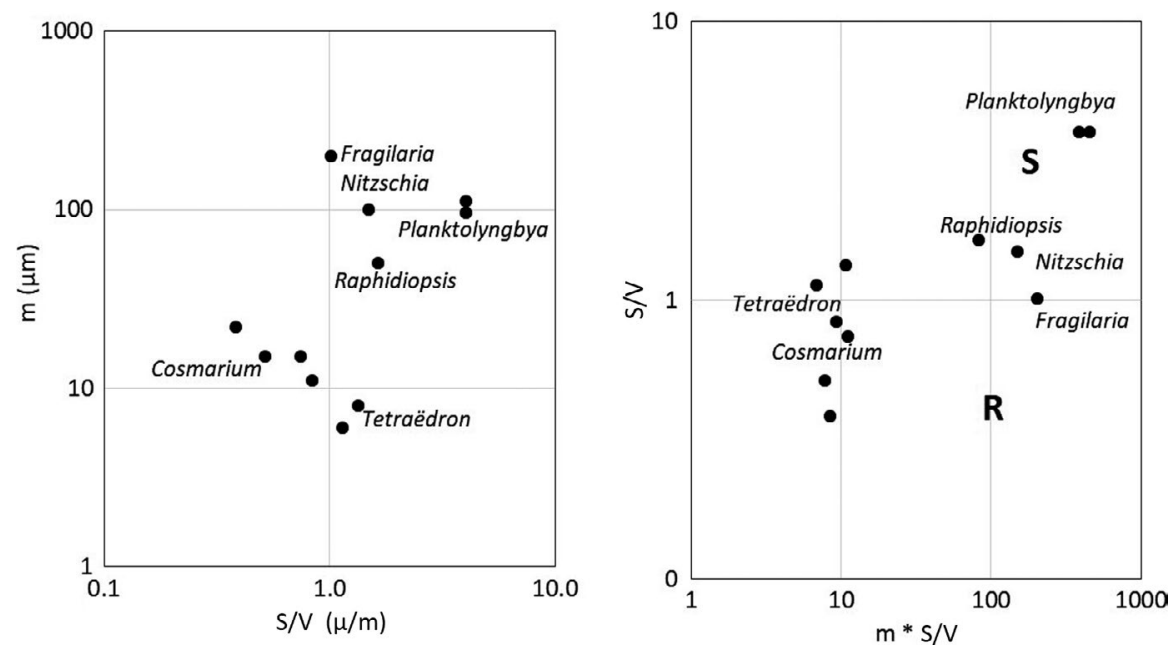

FIGURE 5 Morphological parameters of the most abundant phytoplankton taxa in Lake Kivu in 2012-2014. $\mathrm{m}$ = greatest axial linear dimension; $\mathrm{S} / \mathrm{V}$ is the ratio between surface area and volume of the cells or filaments. There are two Planktolyngbya species ( $P$. contorta and P. limnetica), 4 Cosmarium forms/taxa (Cosmarium sp., C. polygonatum and C. laeve, small and large cells), and 2 forms of Tetraëdron minimum, normal and lemonshaped. On the right panel, $\mathrm{S}$ refers to the stress-tolerant strategy, and R to the ruderal strategy, according to Reynolds (2006)

$56.1 \%$ of the variance of the biomass of the phytoplankton classes, with Zm, Zm:Zeu, Delta_T, PON, and POP as main driving variables. The analysis separated well the 2005-2008 period, with higher water column stability (Schmidt stability index, Delta_T) favouring high biomass of cyanobacteria T2 and cryptophytes, and the 20122014 period, with higher mixed layer depth ( $\mathrm{Zm}, \mathrm{Zm:Zeu}$ ), higher particulate nutrients (PON, POP) and higher green algae, cyanobacteria $\mathrm{T} 1$ and diatom biomass.

\subsection{Temperature data from the lake loggers}

The examination of water column temperature time-series acquired at high temporal resolution (at 10 m intervals) in 2012-2014, suggests that mixing may have occurred on a daily basis down to 20 $(-30) \mathrm{m}$ depth, even in the rainy season. Figure 11 shows an example extracted from the lake logger database: in the 2 first weeks of January 2013, the top layers of the lake cooled at night, so that the 
FIGURE 6 Ordination on the two-first axis of the factorial correspondence analysis of the phytoplankton biomass data of the 3 sites studied in Lake Kivu from 2002 to 2014. Sampling points have been linked by year, whose centroids are indicated by the year labels. F1 $=58 \%$ and $\mathrm{F} 2=26 \%$ of projected inertia

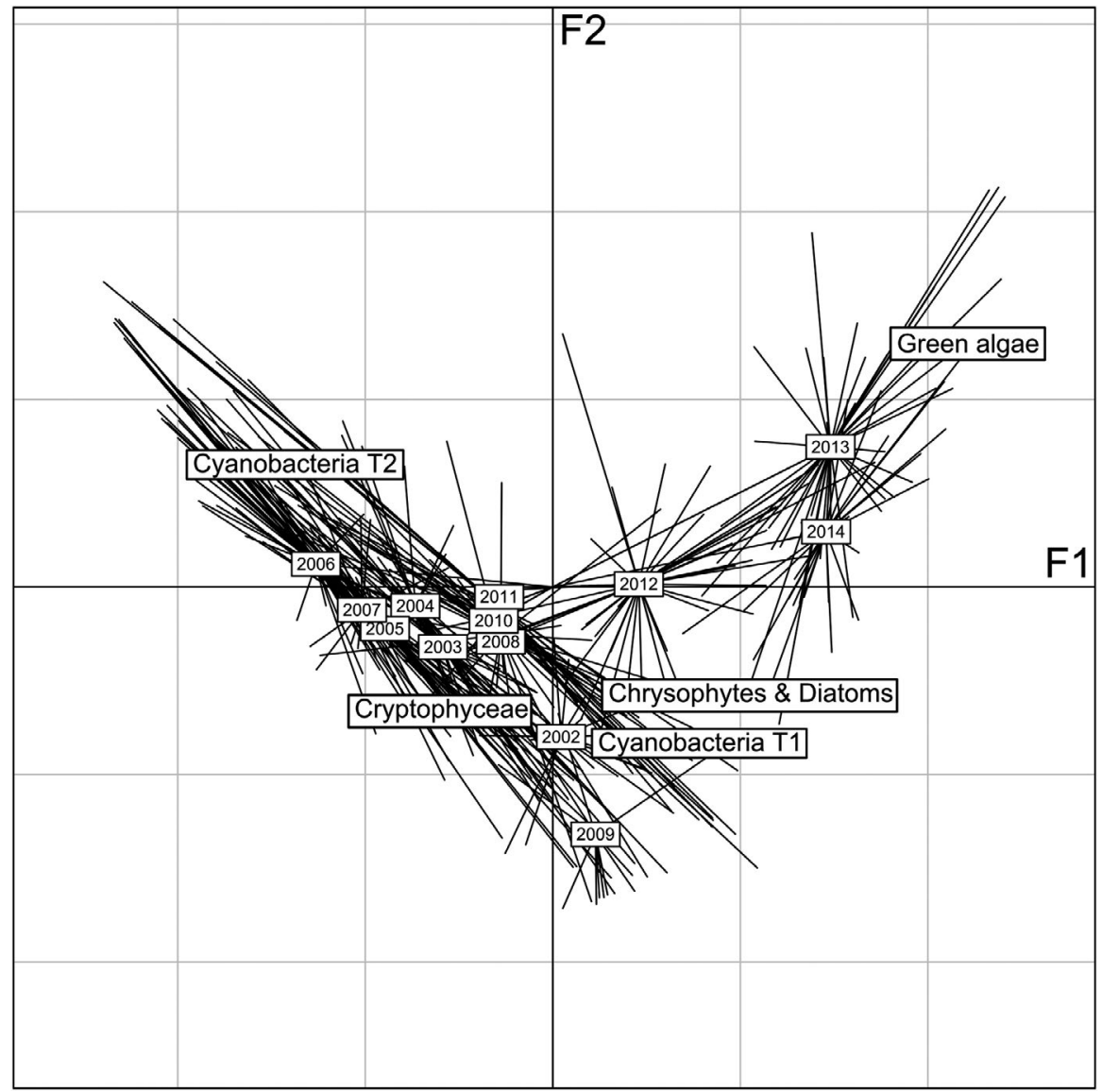

temperature gradient disappeared down to $30 \mathrm{~m}$, potentially allowing vertical mixing to occur. During the day, water temperature went up in the upper layers, generating a temporary stratification. Hence, the lake mixolimnion may have experienced a partial mixing every night, down to 20 or $30 \mathrm{~m}$, depending on the cooling extent.

\section{4 | DISCUSSION}

Here, we report substantial changes on the phytoplankton assemblage of Lake Kivu related with non-seasonal multiannual changes on environmental conditions. Cryptophytes and cyanobacteria declined (from 25 to 7\% lake-wide) in the period 2012-2014 in comparison with 2002-2008, and there was a dramatic rise of green algae (from 3 to $33 \%$ lake-wide), leading to an increase in Chla concentration. In parallel, the two periods also differed in the mixed layer depth, resulting from changes in the thermal gradient. The euphotic zone depth was reduced in 2012-2014, probably from the higher phytoplankton biomass. Moreover, the mean particulate $\mathrm{N}, \mathrm{P}$, and $\mathrm{N}: \mathrm{P}$ ratio were greater in 2012-2014 than in 2002-2008, suggesting changes in nutrient supply resulting in greater $\mathrm{P}$ limitation.

The main objective of this study was to explain these long-term changes, which occurred at the scale of the whole lake. The contrasting survival strategies of the main phytoplankton groups point to a change in the lake's mixing dynamics of the mixolimnion, as evidenced by the trends we identified in the environmental data. Diatoms and non-motile green algae such as those present in Lake Kivu require vertical mixing to remain in suspension (Reynolds, 2006). This is reflected, for instance, in the dry season peaks of diatoms reported from studies of phytoplankton in large, deep tropical lakes (Descy et al., 2005; Hecky \& Kling, 1987; Sarmento et al., 2006, 2007, 2012). Conversely, cyanobacteria T2 correspond in Lake Kivu to filamentous forms, some with gas vesicles (Sarmento et al., 2012), making them able to remain in suspension in the rainy season conditions, when the mixolimnion is stratified. The fact that some of them can, through $\mathrm{N}_{2}$-fixation, withstand a reduced $\mathrm{N}$ supply resulting from increased denitrification that occurs at the oxic-anoxic interface in stratified conditions (Roland et al., 2018) may also have contributed to their success in the period 2002-2008.

This reasoning leads to the hypothesis that the change in phytoplankton composition may have also been driven by a change in nutrient cycling, as evidenced by the significant increase of PON, POP, and the N:P ratio. The fact that both PON and POP increased may be related to the increase in green algae and diatom biomass, as suggested by the CCA results. Regarding changes in dissolved nutrients concentration, few data are available, as SRP and DIN are often below detection level in the euphotic zone of the lake. Sarmento et al. (2006) reported mean SRP between $0.44 \mu \mathrm{M}$ (rainy season) and $0.75 \mu \mathrm{M}$ (dry season), and mean DIN between 2.42 (rainy season) and 3.29 $\mu \mathrm{M}$ (dry season). A few recent data for 2012-2014 reported 

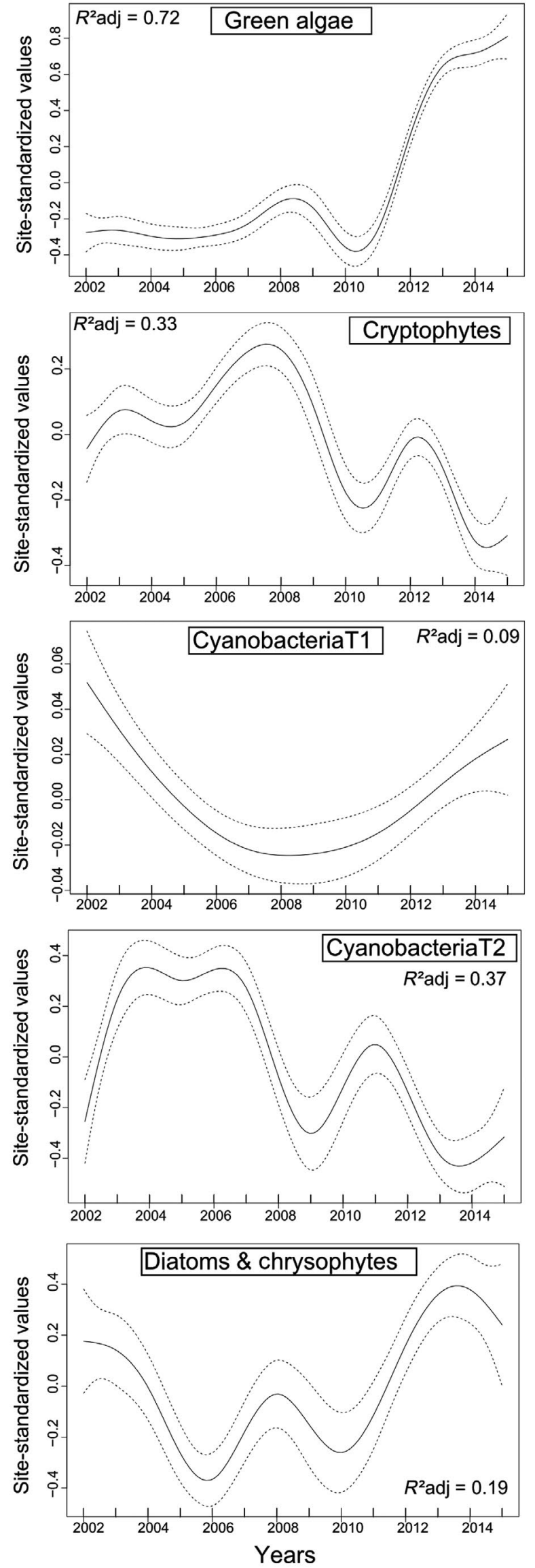

FIGURE 7 Interannual trends of phytoplankton groups in Lake Kivu (2002-2015), as modelled with generalised additive model using data of all sites. Between-site deviations are provided by the dotted lines

TAB LE 1 Trends of the generalised additive model tests applied to phytoplankton biomass in Lake Kivu measured on three sites on the 2002-2014 period ( $\$, decrease; $\nearrow$, increase; -, no trend)

\begin{tabular}{llll} 
& Temporal trend & Adjusted $R^{2}$ & $p$-value \\
\hline Green algae & $\nearrow$ & 0.72 & $<0.001$ \\
\hline Cryptophyceae & $\searrow$ & 0.33 & $<0.001$ \\
\hline Cyanobacteria T1 & - & 0.09 & \\
Cyanobacteria T2 & $\searrow$ & 0.37 & $<0.001$ \\
\hline $\begin{array}{c}\text { Diatoms and } \\
\text { chrysophytes }\end{array}$ & $\nearrow$ & 0.19 & $<0.001$ \\
Dinoflagellates & - & & \\
\hline
\end{tabular}

$0.49 \mu \mathrm{M}$ for DIN in the surface waters (0-30 m; Roland et al., 2018), suggesting a substantial decrease of DIN, whereas C:N particulate ratios did not change. There are unfortunately no reliable values for SRP, nor in C:P in the seston after Sarmento et al.'s study. Whether the DIN decrease is a cause or an effect of the recent changes in phytoplankton biomass in uncertain. We think it more likely that the increase in phytoplankton biomass resulted in a higher nutrient demand, reflected by the higher $\mathrm{N}$ and $\mathrm{P}$ concentration in the seston, and drove dissolved nutrient concentrations down. Nevertheless, it cannot be ruled out that these lower concentrations of DIN resulted also from other changes in the nutrient cycling processes, which are complex, depending on upward fluxes from the deep water (Pasche, Muvundja, Schmid, Wüest, \& Müller, 2012) and from processes (e.g. nitrification, denitrification, anaerobic methane oxidation; see Roland et al., 2018) occurring within the anoxic-oxic interface of the lake and in its lower mixolimnion.

Overall, greater $\mathrm{P}$ limitation might have favoured species with comparatively low nutrient requirements (Kilham et al., 1986), as thin, needle-like diatoms such as Fragilaria danica and Nitzschia bacata (Sarmento et al., 2007) and possibly Cosmarium laeve, which is by far the most abundant species presently in Lake Kivu. There are few data on the nutrient and other ecological requirements of this particular species, which is known as widespread and cosmopolitan in different waters of the world-from oligotrophic to eutrophic with high mineralisation and wide range of $\mathrm{pH}$ (e.g. Brook, Williamson, \& John, 2011; Coesel \& Meesters, 2007; Kogan \& Gorbanj, 1964; Palamar-Mordvintseva, 1982; Sharf, 1985). The effect of underwater light on desmids is also underexplored with contrasting data on species from oligo- and eutrophic waters (review in Barbosa, Barbosa, Araujo, \& Bicudo, 2013;). However, the main distribution of Cosmarium laeve in small shallow water bodies, including ditches, cattle troughs, municipality fountains, and sulfur springs (e.g. Brook et al., 2011; Hindák \& Hindáková, 1994), may indicate its preference to high-light conditions, which are prevailing in the clear water 



FIG URE 8 Seasonal and interannual trends of limnological variables in Lake Kivu (2002-2015), as modelled with generalised additive model using data of all sites. The seasonal pattern is shown on the left panel (months numbered from 1 to 12 ) and the interannual pattern on the right panel. The dotted lines correspond to the $95 \%$ confidence interval. Zm, depth of the mixed layer; Zeu, euphotic layer thickness; Chla, chlorophyll $a$; Tmax, maximum temperature; Tmin, minimum temperature; DeltaT, Tmax - Tmin

column of the tropical, oligotrophic Lake Kivu. Accordingly, the genus Cosmarium is considered, among the green algae, as tolerant to chronically oligotrophic conditions (Reynolds, 2006, table 5.2).
According to the S/V and $\mathrm{mS} / \mathrm{V}$ this desmid seems to exploit a transitional S-R (i.e. stress-tolerant vs. ruderals, see the review by Olrik, 1994) life-strategy, which includes low sensitivity to grazing. 
TAB LE 2 Trends of the generalised additive model tests applied to physical parameters in Lake Kivu measured on three sites on the 2002-2014 period ( $\searrow$, decrease; $\nearrow$, increase; -, no trend)

\begin{tabular}{lllr} 
& Temporal trend & Adjusted $R^{2}$ & $p$-value \\
Zm & $\nearrow$ & 0.56 & $<0.001$ \\
Zeu & $\searrow$ & 0.20 & 0.003 \\
\hline Chla & $\nearrow$ & 0.15 & $<0.001$ \\
Tmax & $\searrow$ & 0.50 & $<0.001$ \\
Tmin & $\nearrow$ & 0.28 & $<0.001$ \\
Delta T & $\searrow$ & 0.48 & $<0.001$ \\
\hline
\end{tabular}

Chla, chlorophyll a concentration; DeltaT, Tmax - Tmin; Tmax, maximal temperature in the mixolimnion; Tmin, minimal temperature in the mixolimnion; Zeu, euphotic layer thickness; Zm, depth of the mixed layer.

Its low S/V ratio along with its thick cell wall implies high sinking rates, which is why atelomixis is key to keep them in suspension in the water column (Barbosa \& Padisák, 2002), as discussed in detail below. Since nutrient deficiency, and strong P-limitation in particular, supports the development of S-strategists (Olrik, 1994), the overlapping S-R strategy of the species may explain its success in the oligotrophic conditions of Lake Kivu. Thus, high light and low nutrients, associated with frequent partial mixing of the water column and possibly low losses related with zooplankton grazing, may be key to the success of Cosmarium laeve in Lake Kivu. Descy et al. (2010) and Stoyneva, Descy, and Vyverman (2007), Stoyneva et al. (2012) emphasised the importance of grazing on phytoplankton selection in large tropical lakes, where metazooplankton is present all year round. This selection favours large unicells, as Eremosphaera in Lake Tanganyika, or coenobial and colonial forms, such as Lobocystis and Nitzschia asterionelloides O. Müller in Lake Tanganyika again. It is quite likely that the medium size of Cosmarium laeve (m 15-20 $\mu \mathrm{m}$ ) and thick cell wall provided some grazing resistance, contributing to its survival in Lake Kivu mixolimnion.

The hypothesis proposed to explain the success of non-motile phytoplankton taxa in Lake Kivu mixolimnion is supported by the increasing trend the mixed layer depth, which obviously favoured diatoms and non-motile green algae, at the expense of filamentous cyanobacteria and cryptophytes, which showed a strong decline in the recent years, probably as a result of the reduction of seasonal stratification. However, there is necessarily a process operating at the scale of algal population lifetime, i.e. days or weeks. Indeed, for an algal population to maintain itself, it must have a growth rate greater than the losses due to mortality, grazing and, above all in a stratified lake, sedimentation. Settling losses depend on the specific sinking rate of the algal cells ( $\mathrm{m} /$ day) determined by their size, shape and density, but depend also on the depth of the mixed layer, that can be linked to the thermal gradient, and to the vertical turbulent intensity (Reynolds, 2006). We have shown, from the high-frequency temperature logger records in the mixolimnion of Lake Kivu that a daily cooling of the water column may occur, suppressing the thermal gradient in the 0-20 (30) $\mathrm{m}$ layer for a few hours at night, allowing partial vertical mixing of the water column. In this way, the mixolimnion can alternate between periods of stratification of the upper lake layer during the day and periods of mixing at night. This is on some way analogous to the behaviour of tropical shallow lakes, which are polymictic, such as Lake George in Uganda (Talling \& Lemoalle, 1998). However, here the water column mixing occurs only partially, a phenomenon referred to as atelomixis. Barbosa and Padisák (2002) mentioned this "forgotten lake stratification pattern", rarely found in limnology textbooks, in a study of two Brazilian lakes of moderate size and depth, and used the term partial atelomixis as the diurnal vertical mixing did not suppress the seasonal thermocline in these lakes. So this mixing dynamics is definitely different from the complete mixing observed in shallow tropical lakes, as far as nutrient cycling is concerned: while the water column mixes partially, nutrients accumulated in the deeper layers do not reach the euphotic layer, which can remain nutrient-limited, allowing only survival of the algae with low nutrient requirement.

Atelomixis has been reported in a number of warm low-latitude lakes (Becker, Cardoso, \& Huszar, 2008; Bouvy et al., 2003; Fetahi, Schagerl, \& Mengistou, 2014; Gunkel \& Casallas, 2002; Lopes, Bicudo, \& Ferragut, 2005; Souza, Barros, Barbosa, Hajnal, \& Padisák, 2008), and in some of those, desmids dominance has been attributed to this mixing pattern. A new Reynolds' functional group (Reynolds, Huszar, Kruk, Naselli-Flores, \& Melo, 2002) has been suggested: $\mathrm{N}_{\mathrm{A}}$ (atelomixis-dependent desmids) for this particular phytoplankton assemblage (Souza et al., 2008). However, Lake Kivu is very different from those lakes cited above, which were less deep, mixing completely
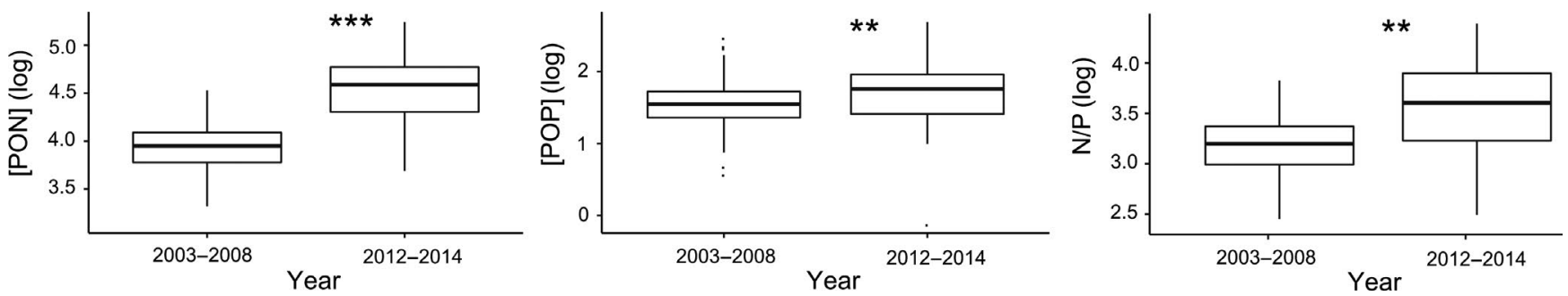

FIG URE 9 Box-plots of natural logarithm of particulate N (PON), particulate $P(P O P)$, and N:P molar ratios in the seston observed in all study sites, from 2003 to 2014 . All data from the different basins have been merged. Dark lines represent the median and the middle boxes encompass $50 \%$ of the observations from lower (25\%) to upper (75\%) quartiles. The upper and lower whiskers describe, respectively, the extreme quartiles. Outliers are displayed as black circles. Stars indicate statistical significance at $p<0.05\left({ }^{*}\right), p<0.01\left({ }^{* *}\right)$ and $p<0.001\left(^{* * *}\right)$ tested with an ANOVA 


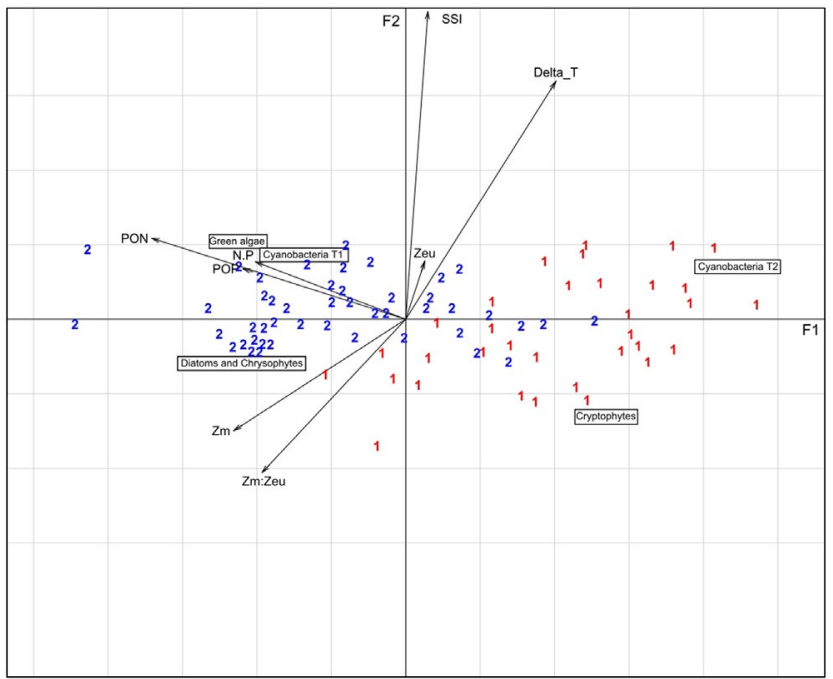

FIGURE 10 Ordination depicting the first two axes of the canonical correspondence analysis of the phytoplankton biomass data and the limnological data of the northern and eastern sites studied in Lake Kivu from 2005 to 2014. Positions of the species assemblages are framed in black boxes. Positions of observations are indicated with a red 1 for the 2005-2008 period and a blue 2 for the 2012-2014 period. The first axis (F1) encompassed $88.5 \%$ of the projected inertia and the second axis (F2) $7.3 \%$. The environmental variables (see text for acronyms) explained $56.1 \%$ of the variance of the biomass of the phytoplankton classes [Colour figure can be viewed at wileyonlinelibrary.com]

seasonally and in most cases supporting much higher phytoplankton diversity and biomass. Lake Kivu is probably a rare example of atelomeromictic lake. More interestingly, in many of those lakes the same algal group was very abundant: desmids, despite their assumed high specific sedimentation rate, remained in the plankton, due to the partial mixing of the water column at night. Therefore, we reinforce the hypothesis (see Barbosa \& Padisák, 2002) that atelomixis may be a key process in low latitude lakes, essential to understand phytoplankton dynamics, and largely overlooked because of the need of high-frequency measurements to be detected.

The changes reported here overcome seasonal fluctuations in phytoplankton composition. There was a pronounced non-seasonal shift on core phytoplankton community structure that can only be explained by a climate variability over East Africa that operates at a decadal-multidecadal scale (Tierney et al., 2013). Apparently, these multiannual regime shifts are stronger than seasonal fluctuations of community structure, and it is likely that green algae were at times abundant in Lake Kivu in the past. For instance, Hecky and Kling (1987) reported several Cosmarium amongst the most abundant species in samples from March 1972. Additional evidence of variation of phytoplankton assemblage structure in the past is provided by data on fossil pigments in the sediment, where lutein, a carotenoid specific to green algae, shows great variations over the depth of a sediment core (Descy et al., 2015). Lutein concentration was low in surface sediments, whereas it was quite high in deeper strata, where diatoms were also more abundant.
Tropical lakes, given their usually weak thermal gradient, respond quickly in changes in atmospheric conditions that may be driven by climate variability (e.g. Nicholson, 1996). This may be particularly true for Lake Kivu, given its location at relatively high altitude, which determines a mean surface temperature of $c .24^{\circ} \mathrm{C}$ and a thermal gradient in the mixolimnion in the rainy season of c. $2^{\circ} \mathrm{C}$ (Schmid \& Wüest,2012). Hence, the intensity of vertical mixing shows a great sensitivity to meteorological conditions, particularly in the dry season (Schmid \& Wüest,2012) but also to those of the preceding rainy season (Darchambeau et al., 2013). This results in a great interannual variability of the intensity of the dry season mixing, which drives phytoplankton biomass and primary production (Darchambeau et al., 2014). Climate variability occurring at a decadal-multidecadal scale in East Africa (Tierney et al., 2013) is influenced by teleconnections with both Indian and Pacific Ocean sea surface temperatures. Correspondingly, for Lake Kivu, Darchambeau et al. (2013) have observed statistically highly significant correlations between intra- and inter-annual variations of water column stability, phytoplankton biomass and tropical ocean climate indexes, including western tropical Indian Ocean sea surface temperature anomaly index, dipole mode index, Southern Ocean Index, and EI Niño-Southern Oscillation. It is very likely that the changes we report for Lake Kivu in mixed layer depth, decrease of the temperature gradient and phytoplankton assemblage structure are driven by the same large-scale variability. The lack of high-quality meteorological data for the 2002-2008 period makes it impossible to provide evidence for a change of weather pattern in the Lake Kivu region. We can just speculate that drier, clear sky conditions at night induced greater energy loss (longwave radiative cooling), allowing deeper mixing. This would be consistent with the slight reduction in stratification strength (Figure 2), possibly related to the transition from a wet to a drier period.

Finally, only long-term surveys over many years can capture the kind of variability, inducing regime shifts depending on large scale climate variation, we observed in a tropical large lake. A study covering a few years would have shown that the pelagic zone of Lake Kivu was dominated by cyanobacteria and diatoms, with very few green algae (Sarmento et al., 2006), contrasting both with previous reports (Hecky \& Kling, 1987) and with the present situation. Moreover, a survey based only on Chla measurements would have shown a modest recent increase of phytoplankton biomass, which might have been interpreted as the result of nutrient enrichment, possibly from changes in fluxes from the deep waters to the mixolimnion, or from increasing inputs from the watershed. Only more detailed data including phytoplankton community structure allowed us to point out the effects of a change in the water column mixing pattern. Similar shifts in phytoplankton community structure might be expected in other East African Great Lakes, but they can only be detected if long-term limnological and planktological data (or paleoproxies) are available. This study also allows to insist that high-quality limnological, planktological, and meteorological data are needed for the monitoring, conservation and management of the African inland waters (Robarts \& Zohary, 2018), which provide key resources for the local populations. 

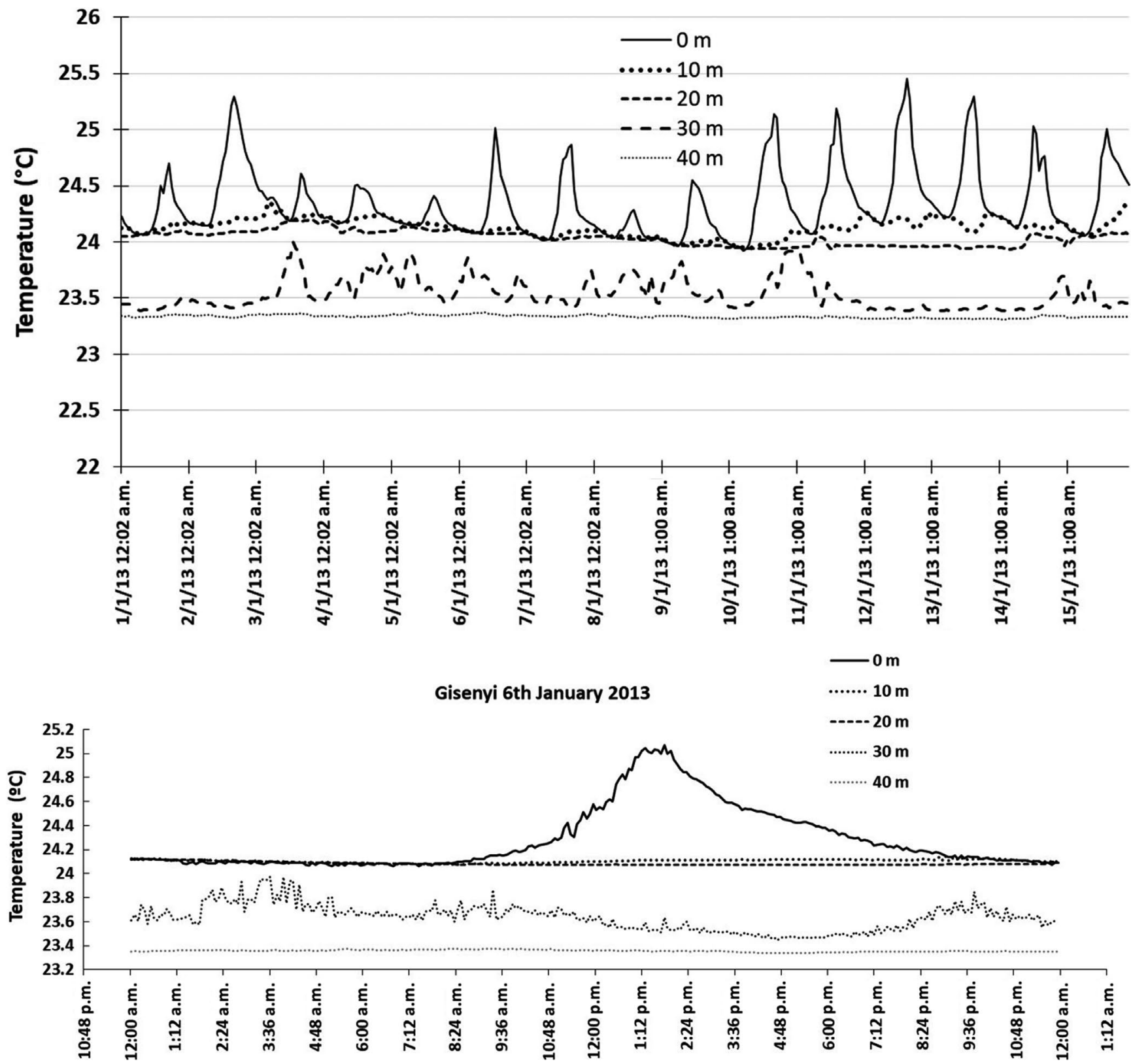

FIG URE 11 Example of changes in temperature in Lake Kivu off Gisenyi (2013), northern basin, as recorded by thermistors deployed between 0 and $40 \mathrm{~m}$ depth

\section{ACKNOWLEDGMENTS}

The data used in this study, originating from different projects supported by CUD (Coopération Universitaire pour le Développement, FRS-FNRS (Fonds National de la Recherche Scientifique), CTB (Coopération Technique Belge), and BELSPO (Belgian Scientific Policy Office), were gathered during the EAGLES project, supported by BELSPO (Belgian Scientific Policy Office; www.belspo.be) under the Science for Sustainable Development (contract SD/AR/02A). The collaboration with the teams from ISP Bukavu and University of Rwanda was invaluable. H.S.'s work was supported by CNPq (grant 309514/2017-7) and FAPESP (process 2014/14139-3). The authors are grateful to the editor of FWB and to one referee, who both made constructive comments that helped improve the manuscript.
ORCID

Jean-Pierre Descy iD https://orcid.org/0000-0003-1649-7800

\section{REFERENCES}

AFNOR (2006). Qualité de l'eau - Norme guide pour le dénombrement du phytoplancton par microscopie inversée (méthode Utermöhl). NF EN 15204 Décembre 2006.

Anneville, O., Ginot, V., Druart, J.-C., \& Angeli, N. (2002). Long-term study (1974-1998) of seasonal changes in the phytoplankton in Lake Geneva: a multi-table approach. Journal of Plankton Research, 24, 993-1008. https://doi.org/10.1093/plankt/24.10.993

Barbosa, L. G., Barbosa, F. A. R., Araujo, G. J. M, \& Bicudo, C. E. D. M. (2013). The dominance of desmids in tropical monomictic lakes (SE Brazil). Limnetica, 32, 71-86. 
Barbosa, F. A. R., \& Padisák, J. (2002). The forgotten lake stratification pattern: atelomixis, and its ecological importance. Verhandlungen Internationaler Vereinigung der Limnologie, 28, 1385-1395.

Becker, V., Cardoso, L. S., \& Huszar, V. L. M. (2008). Diel variation of phytoplankton functional groups in a sub-tropical reservoir in southern Brazil during an autumnal stratification period. Aquatic Ecology, 43, 285-293. https://doi.org/10.1007/s10452-008-9164-0

Bergamino, N., Horion, S., Stenuite, S., Cornet, Y., Loiselle, S., Plisnier, P.-D., \& Descy, J.-P. (2010). Spatio-temporal dynamics of phytoplankton and primary production in Lake Tanganyika using a MODIS based bio-optical time series. Remote sensing of Environment, 114, 772-780. https://doi.org/10.1016/j.rse.2009.11.013

Borges, A. V., Abril, G., Delille, B., Descy, J. P., \& Darchambeau, F. (2011). Diffusive methane emissions to the atmosphere from Lake Kivu (Eastern Africa). Journal of Geophysical Research: Biogeosciences, 116(G3).

Bouvy, M., S. Nascimento, M., Molica, R. J. R., Ferreira, A., Huszar, V., \& Azevedo, S. M. F. O. (2003). Limnological features in Tapacurá reservoir (northeast Brazil) during a severe drought. Hydrobiologia, 493, 115-130. https://doi.org/10.1023/a:1025405817350

Brook, A.J., Williamson, D.B., \& John, D.M. (2011). Phylum Chlorophyta. Suborder Desmidiineae. In: D.M. John, B.A. Whitton \& A.J. Brook (Eds.), The freshwater algal flora of the British Isles. An identification guide to freshwater and terrestrial algae (pp. 636-741), 2nd edition. Cambridge: Cambridge University Press.

Chessel, D., Dufour, A.-B., \& Thioulouse, J. (2004). The ADE4 package-IOne-table methods. $R$ News, 4, 5-10.

Coesel, P., \& Meesters, K. (2007). Desmids of the Lowlands - Mesotaeniaceae and Desmidiaceae of the European Lowlands. The Netherlands: KNNV Publishing. https://doi.org/10.1163/9789004277922

Darchambeau, F., Borges, A. V., Sarmento, H., Leporcq, B., Isumbisho, P. M., Alunga, G., ... Descy, J.-P. (2013). Teleconnections between ecosystem productivity and climate indices in a tropical great lake. Geophysical Research Abstracts, 15, EGU2013-9919-1.

Darchambeau, F., Sarmento, H., \& Descy, J. P. (2014). Primary production in a tropical large lake: The role of phytoplankton composition. The Science of the Total Environment, 473-474, 178-188. https://doi. org/10.1016/j.scitotenv.2013.12.036

De Senerpont Domis, L. N., Elser, J. J., Gsell, A. S., Huszar, V. L. M., Ibelings, B. W., Jeppesen, E., ... Lürling, M. (2013). Plankton dynamics under different climatic conditions in space and time. Freshwater Biology, 58, 463-482. https://doi.org/10.1111/fwb.12053

Descy, J. P., André, L., Delvaux, C., Monin, L., Bouillon, C., \& Morana, C. V., ... Nyinawamwiza, L. (2015). East African Great Lake Ecosystem Sensitivity to changes. Final report. Belgian Science Policy (Research Programme Science for a Sustainable Development). http://www. belspo.be/belspo/SSD/science/Reports/EAGLES_FinRep.pdf

Descy, J.-P., Darchambeau F. \& Schmid, M. (2012). Lake Kivu: Limnology and Biogeochemistry of a tropical great lake. Aquatic Ecology Series (192 p), The Netherlands: Springer.

Descy, J.-P., \& Guillard, J. (2014) Biological Baseline of Lake Kivu: Final report. Université de Namur \& Carrtel, 33 p.

Descy, J.-P., Hardy, M.-A., Sténuite, S., Pirlot, S., Leporcq, B., Kimirei, I., ... Sinyenza, D. (2005). Phytoplankton pigments and community composition in Lake Tanganyika. Freshwater Biology, 50, 668-684. https ://doi.org/10.1111/j.1365-2427.2005.01358.x

Descy, J.-P., Tarbe, A.-L., Stenuite, S., Pirlot, S., Stimart, J., Vanderheyden, J., ... Plisnier, P.-D. (2010). Drivers of phytoplankton diversity in Lake Tanganyika. Hydrobiologia, 653, 29-44. https://doi.org/10.1007/ s10750-010-0343-3

Development Core Team, R. (2010). R: A language and environment for statistical computing. Vienna, Austria: R Foundation for Statistical Computing.

Fetahi, T., Schagerl, M., \& Mengistou, S. (2014). Key drivers for phytoplankton composition and biomass in an Ethiopian highland lake. Limnologica, 46, 77-83. https://doi.org/10.1016/j.limno.2013.10.007
Fewster, R. M., Buckland, S. T., Siriwardena, G. M., Baillie, S. R., \& Wilson, J. D. (2000). Analysis of population trends for farmland birds using generalized additive models. Ecology, 81, 1970-1984. https://doi.org/10.1890/0012-9658(2000)081[1970:aoptf f]2.0.co; 2

Fietz, S., \& Nicklisch, A. (2004). An HPLC analysis of the summer phytoplankton assemblage in Lake Baikal. Freshwater Biology, 49, 332-345. https://doi.org/10.1111/j.1365-2427.2004.01183.x

Fietz, S., Sturm, M., \& Nicklisch, A. (2005). Flux of lipophilic photosynthetic pigments to the surface sediments of Lake Baikal. Global and Planetary Change, 46, 29-44. https://doi.org/10.1016/j.glopl acha.2004.11.004

Ginn, B. K., Cumming, B. F., \& Smol, J. P. (2007). Assessing pH changes since pre-industrial times in 51 low-alkalinity lakes in Nova Scotia, Canada. Canadian Journal of Fisheries and Aquatic Sciences, 64, 10431054. https://doi.org/10.1139/f07-078

Grime, J. P. (1979). Plant strategies and vegetation processes. Chichester: John Wiley \& Sons.

Grime, J. P. (2001). Plant strategies, vegetation processes and ecosystem properties. Chichester: John Wiley \& Sons.

Gunkel, G., \& Casallas, J. (2002). Limnology of an equatorial high mountain lake-Lago San Pablo, Ecuador: The significance of deep diurnal mixing for lake productivity. Limnologica, 32, 33-43. https://doi. org/10.1016/s0075-9511(02)80015-9

Haberyan, K. A., \& Hecky, R. E. (1987). The late Pleistocene and Holocene stratigraphy and paleolimnology of lakes Kivu and Tanganyika. Paleogeography, Paleoclimatology, Paleoecology, 6, 169-197. https:// doi.org/10.1016/0031-0182(87)90048-4

Hecky, R. E., \& Kling, H. J. (1987). Phytoplankton ecology of the great lakes in the rift valleys of Central Africa. Archiv für HydrobiologieBeiheftErgebnisse der. Limnologie, 25, 197-228.

Hindák, F., \& Hindáková, A. (1994). Some interesting observations on desmids (Conjugatophyceae). Biologia Bratislava, 49, 525-533.

Horion, S., Bergamino, N., Stenuite, S., Descy, J.-P., Plisnier, P.-D., Loiselle, S. A., \& Cornet, Y. (2010). Optimized extraction of daily bio-optical time series derived from MODIS/Aqua imagery for Lake Tanganyika, Africa. Remote sensing of Environment, 114, 781-791. https://doi. org/10.1016/j.rse.2009.11.012

Jeffrey, S. W., Mantoura, R. F. C., \& Bjørnland, T. (1997). Data for the identification of 47 key phytoplankton pigments. In S. W. Jeffrey, R. F. C. Mantoura, \& S. W. Wright (Eds.), Phytoplankton Pigments in Oceanography: guidelines to modern methods (pp. 449-559). Paris: SCOR-UNESCO.

Kilham, P., Kilham, S. S., \& Hecky, R. E. (1986). Hypothesized resource relationships among African planktonic diatoms. Limnology and Oceanography, 31, 1169-1181. https://doi.org/10.4319/lo.1986. 31.6.1169

Kogan, S.I., \& Gorbanj, V.E. (1964). Ad floram Desmidiacearum in aquaris Turkomaniae. Novosti systematiki nizschih rastenii, M.L. Izd-vo AN SSSR, 19-30(In Russian).

Lliros, M., Descy, J.-P., Libert, X., Morana, C., Schmitz, M., Wimba, L., ... Darchambeau, F. (2012). Microbial ecology of Lake Kivu. In: J.-P. Descy, F. Darchambeau \& M. Schmid. Lake Kivu: Limnology and Biogeochemistry of a tropical great lake. Aquatic Ecology Series, The Netherlands: Springer, 85-105. https://doi. org/10.1007/978-94-007-4243-7

Lopes, M. R. M., Bicudo, C. E. d. M., \& Ferragut, M. C. (2005). Short term spatial and temporal variation of phytoplankton in a shallow tropical oligotrophic reservoir, southeast Brazil. Hydrobiologia, 542, 235-247. https://doi.org/10.1007/s10750-004-8332-z

Maclntyre, S. (2012). Climatic Variability, Mixing Dynamics, and Ecological Consequences in the African Great Lakes. In: C.R. Goldman, M. Kumagai \& R.D. Robarts (Eds.), Climatic Change and Global Warming of Inland Waters: Impacts and Mitigation for Ecosystems and Societies. Hoboken, NJ: Wiley Blackwell, 311-336. 
Mackey, M. D., Mackey, D. J., Higgins, H. W., \& Wright, S. W. (1996). CHEMTAX - A program for estimating class abundances from chemical markers: Application to HPLC measurements of phytoplankton. Marine Ecology-Progress Series, 144, 265-283. https://doi. org/10.3354/meps144265

Nicholson, S. (1996). A review of climate dynamics and climate variability in Eastern Africa. In T. C. Johnson, \& E. Odada (Eds.), Limnology, Climatology and paleoclimatology of the East African lakes (pp. 25-56). Amsterdam: CRC Press.

Olrik, K. (1994). Phytoplankton - Ecology. Determining factors for the distribution of phytoplankton in freshwater and sea (p. 183). Copenhagen: Ministry of Environment of Denmark \& Danish Environmental Protection Agency.

O'Reilly, C. M., Alin, S. R., Plisnier, P. D., Cohen, A. S., \& McKee, B. A. (2003). Climate change decreases aquatic ecosystem productivity of Lake Tanganyika, Africa. Nature, 424(6950), 766-768. https://doi. org/10.1038/nature01833

Palamar-Mordvintseva, G.M. (1982). Opredelitel' presnovodnykh vodoroslei SSSR [Key to Freshwater Algae of the USSR. Vol. 11 Part 2.] Zelenye vodorosli. Klass Kon'yugaty. Poryadok Desmidievye. Chlorophyta, Desminiales (2). pp. 1-620. Leningrad: Nauka Leningradskoe otdelenie. [in Russian]

Pasche, N., Muvundja, F.A., Schmid, M., Wüest, A., \& Müller, B. (2012). Nutrient cycling in Lake Kivu In: J.-P. Descy, F. Darchambeau \& M. Schmid (Eds.), Lake Kivu: Limnology and Biogeochemistry of a tropical great lake. Aquatic Ecology Series (pp. 31-45), The Netherlands: Springer. https://doi.org/10.1007/978-94-007-4243-7

Plisnier, P. D., Nshombo, M., Mgana, H., \& Ntakimazi, G. (2018). Monitoring climate change and anthropogenic pressure at Lake Tanganyika. Journal of Great Lakes Research, 44(6), 1194-1208. https ://doi.org/10.1016/j.jglr.2018.05.019

Reynolds, C.S. (1988). Potamoplankton: Paradigms, paradoxes and prognoses. In: F.E. Round, (Ed.), Algae and the environment (pp. 285-311). Bristol: Biopress.

Reynolds, C. S. (1992). Eutrophication and the management of planktonic algae: What Vollenweider couldn't tell us. In D. W. Sutcliffe, \& J. G. Jones (Eds.), Eutrophication: Research and Application to Water Supply (pp. 4-29). Ambleside: Freshwater Biological Association.

Reynolds, C. S. (2006). Ecology of phytoplankton. Cambridge: Cambridge University Press. https://doi.org/10.1017/cbo9780511542145

Reynolds, C. S., Huszar, V., Kruk, C., Naselli-Flores, L., \& Melo, S. (2002). Towards a functional classification of the freshwater phytoplankton. Journal of plankton research, 24(5), 417-428.

Robarts, R. D., \& Zohary, T. (2018). Limnology and the future of African inland waters. Inland Waters, 8, 399-412. https://doi. org/10.1080/20442041.2018.1481729

Roland, F. A. E., Darchambeau, F., Borges, A. V., Morana, C., De Brabandere, L., Thamdrup, B., \& Crowe, S. A. (2018). Denitrification, anaerobic ammonium oxidation, and dissimilatory nitrate reduction to ammonium in an East African Great Lake (Lake Kivu). Limnology and Oceanography, 63, 687-701. https://doi.org/10.1002/Ino.10660

Rott, E. (1981). Some results from phytoplankton counting intercalibration. Schweizerische Zeitschrift für Hydrologie, 43, 34-62.

Ruggiu, D., Morabito, G., Panzani, P., \& Pugnetti, A. (1998). Trends and relations among basic phytoplankton characteristics in the course of the long-term oligotrophication of Lake Maggiore (Italy). In: M. Alvarez-Cobelas, C.S. Reynolds, P. Sánchez-Castillo \& J. Kristiansen (Eds.), Phytoplankton and Trophic Gradients. Developments in Hydrobiology, (p. 129). Dordrecht: Springer.

Sarmento, H., Amado, A.M., \& Descy, J.-P. (2013). Climate change in tropical fresh waters (comment on the paper 'Plankton dynamics under different climatic conditions in space and time' by de Senerpont Domis et al.). Freshwater Biology, 58, 2208-2210. https://doi. org/10.1111/fwb.12140
Sarmento, H., Darchambeau, F., \& Descy, J. P. (2012). Phytoplankton of Lake Kivu. In: J.-P. Descy, F. Darchambeau \& M. Schmid (Eds.), Lake Kivu: Limnology and Biogeochemistry of a tropical great lake. Aquatic Ecology Series (pp. 67-83), The Netherlands: Springer. https://doi. org/10.1007/978-94-007-4243-7

Sarmento, H., \& Descy, J.-P. (2008). Use of marker pigments and functional groups for assessing the status of phytoplankton assemblages in lakes. Journal of Applied Phycology, 20, 1001-1011. https://doi. org/10.1007/s10811-007-9294-0

Sarmento, H., Isumbisho, M., \& Descy, J.-P. (2006). Phytoplankton ecology of Lake Kivu (Eastern Africa). Journal of Plankton Research, 28, 815-829. https://doi.org/10.1093/plankt/fbl017

Sarmento, H., Isumbisho, M., Stenuite, S., Darchambeau, F., Leporcq, B., \& Descy, J.-P. (2009). Phytoplankton ecology of Lake Kivu (eastern Africa): Biomass, production and elemental ratios. Verhandlungen des Internationalen Vereinigung Limnologie, 30, 709-713.

Sarmento, H., Leitao, M., Stoyneva, M., Couté, A., Compère, P., Isumbisho, M., \& Descy, J.-P. (2007). Species diversity of pelagic algae in Lake Kivu (East Africa). Cryptogamie, Algologie, 28, 245-269.

Saulnier-Talbot, É., Gregory-Eaves, I., Simpson, K. G., Efitre, J., Nowlan, T. E., Taranu, Z. E., \& Chapman, L. J. (2014). Small changes in climate can profoundly alter the dynamics and ecosystem services of tropical crater lakes. PloS one, 9(1), e86561.

Schmid, M., \& Wüest, A. (2012). Stratification, mixing and transport processes in Lake Kivu. In: J.-P. Descy, F. Darchambeau \& M. Schmid (Eds.), Lake Kivu: Limnology and Biogeochemistry of a tropical great lake. Aquatic Ecology Series (pp. 13-29), The Netherlands: Springer. https:// doi.org/10.1007/978-94-007-4243-7.

Schmid, M., Halbwachs, M., Wehrli, B., \& Wüest, A. (2005). Weak mixing in Lake Kivu: New insights indicate increasing risk of uncontrolled gas eruption. Geochemistry, Geophysics, Geosystems, 6, Q07009. https ://doi.org/10.1029/2004gc000892

Shapiro, S., \& Wilk, M. (1965). An analysis of variance test for normality. Biometrika, 52, 591-611. https://doi.org/10.1093/biomet/52. 3-4.591

Sharf, W. (1985). A comparative study of Desmids from the Eifelmaars. Archiv für Hydrobiologie, Supplement 71 (Algological studies, 41), 549-602.

Souza, M. B. G., Barros, C. F. A., Barbosa, F., Hajnal, É., \& Padisák, J. (2008). Role of atelomixis in replacement of phytoplankton assemblages in Dom Helvécio Lake, South-East Brazil. Hydrobiologia, 607, 211-224. https://doi.org/10.1007/s10750-008-9392-2

Stenuite, S., Pirlot, S., Hardy, M. A., Sarmento, H., Tarbe, A. L., Leporcq, B., \& Descy, J. P. (2007). Phytoplankton production and growth rate in Lake Tanganyika: Evidence of a decline in primary productivity in recent decades. Freshwater Biology, 52, 2226-2239. https://doi. org/10.1111/j.1365-2427.2007.01829.x

Stoyneva, M. P., Descy, J. P., Balagué, V., Compère, P., Leitao, M., \& Sarmento, H. (2012). The queer Tetraëdron minimum from Lake Kivu (Eastern Africa): Is it a result of a human impact? Hydrobiologia, 698, 273-283. https://doi.org/10.1007/s10750-012-1092-2

Stoyneva, M. P., Descy, J.-P., \& Vyverman, W. (2007). Green algae in Lake Tanganyika: Is morphological variation a response to seasonal changes? Hydrobiologia, 578, 7-16. https://doi.org/10.1007/ s10750-006-0428-1

Talling, J. F., \& Lemoalle, J. (1998). Ecological dynamics of tropical inland waters. Cambridge: Cambridge University Press.

Ter Braak, C. J. (1986). Canonical correspondence analysis: A new eigenvector technique for multivariate direct gradient analysis. Ecology, 67, 1167-1179. https://doi.org/10.2307/1938672

Thiery, W., Martynov, A., Darchambeau, F., Descy, J.-P., Plisnier, P.-D., Sushama, L., \& van Lipzig, N. P. M. (2014). Understanding the performance of the FLake model over two African Great Lakes. Geoscientific Model Development, 7, 317-337. https://doi. org/10.5194/gmd-7-317-2014 
Thiery, W., Stepanenko, V. M., Darchambeau, F., Fang, X., Jöhnk, K. D., Li, Z., ... van Lipzig, N. P. M. (2014). LakeMIP Kivu: Evaluating the representation of a large, deep tropical lake by a set of one-dimensional lake models. Tellus A, 66, 21390. https://doi.org/10.3402/tellusa.v66.21390

Tierney, J. E., Mayes, M. T., Meyer, N., Johnson, C., Swarzenski, P. W., Cohen, A. S., \& Russell, J. M. (2010). Late-twentieth-century warming in Lake Tanganyika unprecedented since AD 500. Nature Geoscience, 3, 422-425. https://doi.org/10.1038/ngeo865

Tierney, J.E., Smerdon, J. E., Anchukaitis, K. J., \& Seager, R. (2013). Multidecadal variability in East African hydroclimate controlled by the Indian Ocean. Nature, 493, 389-392. https://doi.org/10.1038/nature11785

Valderrama, J. C. (1981). The simultaneous analysis of total nitrogen and total phosphorus in natural waters. Marine Chemistry, 10, 109-122. https://doi.org/10.1016/0304-4203(81)90027-x

Vrba, J., Kopáček, J., Fott, J., Kohout, L., Nedbalová, L., Pražáková, M., ... Schaumburg, J. (2003). Long-term studies (1871-2000) on acidification and recovery of lakes in the Bohemian Forest (central Europe). Science of the Total Environment, 310, 73-85. https://doi.org/10.1016/ s0048-9697(02)00624-1

Wright, S. W., Jeffrey, S. W., Mantoura, R. F. C., Llewellyn, C. A., Bjornland, T., Repeta, D., \& Welschmeyer, N. (1991). Improved HPLC method for the analysis of chlorophylls and carotenoids from marinephytoplankton. Marine Ecology-Progress Series, 77, 183-196. https:// doi.org/10.3354/meps077183

Wüest, A., Jarc, L., Bürgmann, H., Pasche, N. \& Schmid, M. (2012). Methane formation and future extraction in Lake Kivu. In: J.-P. Descy, F. Darchambeau \& M. Schmid, Lake Kivu: Limnology and Biogeochemistry of a tropical great lake. Aquatic Ecology Series (p. 165180), The Netherlands: Springer.

Zuur, A. F., leno, E. N., Walker, N., Saveliev, A. A., \& Smith, G. M. (2009). Mixed effects models and extensions in ecology with R. Mixed effects models. New York, NY: Springer. https://doi. org/10.1007/978-0-387-87458-6

How to cite this article: Rugema E, Darchambeau F, Sarmento $\mathrm{H}$, et al. Long-term change of phytoplankton in Lake Kivu: The rise of the greens. Freshw Biol. 2019;64:19401955. https://doi.org/10.1111/fwb.13383 